\title{
Recommendations for Prevention and Control of Hepatitis C Virus (HCV) Infection and HCV-Related Chronic Disease
}

\author{
Hamid Mohaghegh Shalmani ${ }^{1}$, Mitra Ranjbar $^{2}$ and Amir Houshang Mohammad Alizadeh ${ }^{1 *}$ \\ ${ }^{1}$ Gastroenterology and Liver Diseases Research Center, Shahid Beheshti University of Medical Sciences, Tehran, Iran \\ ${ }^{2}$ Firouzgar Hospital, Department of Infectious Diseases, Iran University of Medical Sciences, Tehran, Iran
}

\begin{abstract}
Hepatitis $\mathrm{C}$ virus is the main cause of chronic liver disease and cirrhosis, and also liver cancer. According to global health importance of hepatitis $\mathrm{C}$, decreasing the burden of HCV infection and HCV-related disease is so important. It need to design and implement preventive activity against HCV infection by introducing primary and secondary prevention activities. Hepatitis $C$ has no effective vaccine. Considering counseling and education of people to avoid risk factors, such as IV drug abusing and having multiple sex partners, are important primary prevention activities.Public health surveillance is an effective strategy to detect new cases, risk factors and burden of disease. Early diagnosis and prompt treatment by expert specialists can decrease hepatitis $\mathrm{C}$ and HCV- related diseases prevalence, disease sequel and burden of hepatitis $\mathrm{C}$. Monitoring and assessment of preventive programs is required to identify the strength and weakness of program and to re-establish newer one.
\end{abstract}

Keywords: Hepatitis C virus; Primary prevention; Secondary prevention; Screening; Public health surveillance

\section{Introduction}

More than 20 years later than discovery of Hepatitis C Virus (HCV), it is now well recognized that HCV is of global health problem, affecting 170-200 million people within all countries, needs active interventions for its prevention and control $[1,2]$. Hepatitis $C$ virus (HCV) infection is now the most prevalent chronic blood borne infection. Although decreasing incidence of new infections has been reported, it is estimated that the burden of HCV increases over the next decade and HCV infection will be a main cause of chronic liver diseases and liver cancer $[2,3]$. On the other hand, psychosocial concerns and Health-Related Quality Of Life (HRQOL) are important in patients with chronic hepatitis C [4].

A person with hepatitis $C$ is a potential source of transmission of virus to others, and also it may result in chronic liver disease within 20 or more years of incident of infection. Hepatitis $C$ virus is the main cause of chronic liver disease and cirrhosis, and also liver cancer in developed countries. Available data show 54,000 deaths and 955,000 disability adjusted life-years associated with acute HCV infection. The major burden from HCV infection is due to complication of chronic HCV infection [5,6]. Because of existence of risk factors in receiving $\mathrm{HCV}$, such as unscreened blood donationunsterile tattooing, IV drug abusing, unsafe sex working and also lack of effective HCV vaccine, new cases of hepatitis are still detected [7-11].

According to global health importance of hepatitis C, decreasing the burden of HCV infection and HCV-related disease is so important. It need to design and implement preventive activity against $\mathrm{HCV}$ infection by introducing primary and secondary prevention activities. This paper introduces some recommendation developed by experts and responsible organizations, including World Health Organization (WHO)a and Centers for Disease Control [12], to reduce the risk of transmission, early diagnosis and proper management of patients (Table 1).

\section{Epidemiology}

Hepatitis C Virus (HCV) infection is now a global public health matter and is endemic to nearly all part of the world [13,14]. It is stillthe most common cause of post-transfusion hepatitis worldwide and is an important cause of end-stage liver disease.

Acute infection of hepatitis $\mathrm{C}$ is usually asymptomatic and it is either accidentally recognized during routine checkup or work up of chronic liver diseases. Most data available for epidemiology of HCV are dependent on HCV seroprevalence studies representing prevalence of existence of hepatitis $C$ virus in the blood. The majority of studies has cross-sectional design and is performed in particular populations, such as blood donors or IV drug abusers, which are not representative of general population [15].

The estimated prevalence of positive anti-HCV patients was 169.7 (2.9\%) million worldwide. Because chronic liver disease is observed in around $75 \%$ of anti-HCV patients, it is estimated that the prevalence of are chronic hepatitis C is approximately $2.2 \%$ (127 million) [14].

$\mathrm{HCV}$ is more prevalent in some countries of Africa and Asia, with the highest reported seroprevalnce of $13.9 \%$ in healthy general population of Egypt; and is lower the industrialized countries, including those located in North America, northern and Western Europe, and Australia [15-17], with the seroprevalence of fewer than 2.5\%. AntiHCV prevalence calculated 1.5\%-5\%for Eastern Europe, 2.5\%-4.9\% for the Western Pacific region, and $1 \%$ to more than $12 \%$ for the Middle East and Central Asia [18]. Egypt has the highest seroprevalence of $\mathrm{HCV}$, especially in the lower part of country while lowest prevalence has been reported from Germany $(0.6 \%)$ and Canada (0.8\%) [19-22]. Among industrialized nations, USA (1.8\%), Japan (1.5-2.3\%), and Italy (2.2\%) had highest HCV seroprevalence [23-28]. A meta-analysis of on

*Corresponding author: Mohammad Alizadeh $\mathrm{AH}$, Shahid Beheshti University of Medical Sciences, Taleghani Hospital, Tehran, Iran, Tel: 0098-21-22432521; Fax: 0098-21-22432517; E-mail: ahmaliver@yahoo.com

Received November 25, 2013; Accepted December 13, 2013; Published December 21, 2013

Citation: Shalmani HM, Ranjbar M, Alizadeh AHM (2013) Recommendations for Prevention and Control of Hepatitis C Virus (HCV) Infection and HCV-Related Chronic Disease. J Liver 3: 147. doi:10.4172/2167-0889.1000147

Copyright: $(2013$ Shalmani HM. This is an open-access article distributed under the terms of the Creative Commons Attribution License, which permits unrestricted use, distribution, and reproduction in any medium, provided the original author and source are credited. 


\begin{tabular}{|l|}
\hline Most common risks \\
\hline History of injection of illicit drugs \\
Blood transfusion prior to screening of donated blood \\
\hline Organ transplant prior to screening of donors \\
Receipt of clotting factor concentrate prior to screening of donated blood \\
History of chronic hemodialysis \\
History of intranasal use of illicit drugs \\
Acquiring a tattoo at an unregulated establishment \\
Incarceration \\
Sex with an HCV-infected partner \\
Being born to an HCV-infected mother \\
Persistently elevated levels of alanine aminotransferase \\
History of needlestick or other sharp or mucosal exposure \\
\hline
\end{tabular}

Table 1: Risk factors for HCV infection [12]

Iranian studies showed $0.9 \%$ seroprevalence of hepatitis C in Iran [28].

Anti-HCV seroprevalence has been studied in selected population, including blood donors and those having risk factors like IV drug abusing, receiving multiple blood transfusion and hemodialysis. In many part of world, participation of people in blood donation is voluntary and there is a medical screening to exclude high-risk donors. Before screening program, blood transfusion was a main route of $\mathrm{HCV}$ transmission, while after establishment a proper screening program as well as testing the received blood for detecting Hepatitis B. Hepatitis C and HIV, blood and blood products are almost entirely safe. Because of setting up screening program, the prevalence of HCV antibodies among all donors was $0.065 \%$ among $1,761,514$ blood donors was registered in Iran [29]. Seroprevalence is prevalent in Injection drug users, especially those who have unsafe behavior like prisoners. The prevalence of HCV in long-standing IV drug users, more than 5 years, is very high, so that it is reported $94 \%$ in the manhattan, New York [30]. The prevalence of HCV has been shown to be $31.5-45 \%$ in incarcerated IV drug users in Iran $[9,31]$. Before introducing HIV prevention program in 1990, most IDUs were infected by HCV within first year of injection. This shows HIV prevention program could also reduce transmission of $\mathrm{HCV}$ among at risk subjects [32].

It is reported that the prevalence of $\mathrm{HCV}$ in high-risk groups such as injecting drug users, hemophilia and thalassemia patients, and those undergoing hemodialysis is as high as 30\%-90\% [33,34]. Seroprevalence study in Iran showed high prevalence of HCV among patients with thallasssemia (25\%) and hemophililia (71.3\%) and undergoing hemodialysis (14.4\% in 1999 and $4.5 \%$ in 2006) [35-37].

\section{Risk Factors}

Several risk factors have been studied, in which many have been determined as independent risk factors of HCV infection [38]. Wellknown risk factors for HCV infection take in Intravenous Drug Use (IVDU) contact with infected blood products, and intranasal drug use. High-risk sexual activity, tattooing, and skin piercing have also been recommended to be associated with increased risk for HCV [39]. As well, mother-to-infant transmission has been established, but it is a rare cause of transmission of hepatitis C [40]. IVDU is the main way of transmission for HCV infection in the developed countries. IVDU is the most important route of $\mathrm{HCV}$ transmission in the USA and Australia [41,42].
Iatrogenic source of HCV infection by using unsterile medical equipment is a rare way of infection spreading in developed countries $[43,44]$, though, there is evidence to re-use syringes or infected medical equipment for different people in many countries [15]. The most dramatic history in this issue is the long-ego applying parenteral therapy for schistosomiasis with tartar in the Egypt by multiple used syringes, so that it has the highest prevalence of HCV in the world [19].

Most countries in the developing world do not screen blood donations for the existence of $\mathrm{HCV}$ due to financial restriction [15]. It may lead to transmit HCV to patients receiving multiple transfusions, such as those who have thallassemia and hemophilia. Developed countries and several developing countries, like Iran, have a filtering system to exclude high risk donors and also proper screening program to detect hepatitis B and C, and HIV in donated bloods [7].

Occupational transmission of HCV infection to health-care workers by needle stick injury is another unusual way of HCV spreading with attack rates as low as $0.3 \%[15,45]$.

Mother-to-infant transmission throughout perinatal transmission is estimated to occur in $2.7-8.4 \%$ of infants born to HCV infected mothers, and it takes an upper proportion in infants born to HIV/HCV co-infected mothers [46].

Several studies showed relationship between HCV Genotype/ Subtype and mode of transmission. Genotypes $3 \mathrm{a}$ and 1a are extremely seen in HCV-infected injection drug users and genotype $1 \mathrm{~b}$ among patients who received blood transfusions [47-49]. Because of blood screening program and changing route of $\mathrm{HCV}$ transmission, $\mathrm{HCV}$ genotype $1 b$ infection are often observed in older patients infected than those have genotypes 1a and $3 \mathrm{a}[50,51]$.

\section{Natural History}

Only $25 \%$ to $35 \%$ of acute HCV infections become symptomatic, usually with mild and non-specific symptoms. Jaundice occurs in $20 \%$ to $30 \%$ of patients. So, acute infection is rarely diagnosed [2].

Chronic hepatitis C occurs in $60-80 \%$ of infected patients and progresses to liver steatosis, fibrosis, cirrhosis, and hepatocellular carcinoma (HCC) [52,53]; and spontaneous resolution is seen in the rest of newly infected patients [54]. The frequency of spontaneous resolution is higher among infected children, young women and a few patients with community-acquired hepatitis $\mathrm{C}$, with the frequency between $42 \%$ and $45 \%$ [55]. The host or environmental factors, such as age, gender, immunity level and environmental healthcare are responsible for rate of progression of hepatitis $\mathrm{C}$ to chronic liver disease and HCC [23,56]. Cirrhosis is developed in $14 \%$ to $45 \%$ of patients after 20 years [55]. Spontaneous resolution or persistence of hepatitis virus is immunologically mediated by the appearance of virus-specific T. Ineffective innate response and poor response to IFN-g allows sustained viral replication $[57,58]$.

Hepatocellular Carcinomas (HCC) ismostly associated with chronic Hepatitis B or C Virus (HCV) infections, with frequency of approximately $80 \%$. The rate of developing HCC amongst HCVinfected patients is between $1 \%$ and $3 \%$ over 30 years. The occurrence of HCC increases with liver fibrosis stage; on the other hand, most subjects of HCV-related HCC happen in patients with advanced fibrosis or cirrhosis [59].

HCV genotypes have variation in geographic distribution and it should be considered in the optimal duration of antiviral therapy and is a main determinant of prognosis. Genotypes 1,2, and 3 are the most 
prevalent genotypes and evenly distributed worldwide. Genotype 4 is more prevalent in the Middle East and Central Africa, while HCV genotype 5 has been isolated almost solely in South Africa. Genotype 6 is seen in South East Asia countries. HCV genotypes 7, 8, and 9 have been isolated mostly in Vietnamese patients, and genotypes 10 and 11 in Indonesia [60]. HCV genotype 1a is the most frequent genotype isolated from Iranian patients $[61,62]$.

\section{Diagnostic Tests}

Diagnostic tests for hepatitis $\mathrm{C}$ virus have advanced noticeably within the past decade [63]. Diagnostic tests for hepatitis $C$ divided into two groups: 1) serological assays that discover antibody to hepatitis $\mathrm{C}$ virus (anti-HCV); and 2) molecular assays that find out, measure, and/or depict HCV RNA genomes. Serological assays are used for screening of anti-HCV, like enzyme immunoassay (EIA), and definitive diagnosis, such as the Recombinant Immunoblot Assay (RIBA). Three generations of anti-HCV tests have been introduced, and the last generation has higher sensitivity for detecting anti HCV [64].

Anti-HCV test results are employed for clinical diagnosis, management of occupational and perinatal contacts, screening asymptomatic people, and public health surveillance [65].

Table 1 shows risk factors for HCV infection[12]. The main screening test for detecting anti-HCV is the enzyme immunoassay (EIA). Table 2 presents sensitivity and positive predictive value of each generation of EIA for Anti-HCV [64].

Second-generation RIBA (RIBA-2), test with the same HCV antigens as EIA-2 in an immunoblot, solved false-positive EIA test results [66]. A third-generation supplemental test (RIBA-3) is more specific than the RIBA-2 test. RIBA-3 uses both HCV-encoded recombinant antigens and synthetic peptides, and it can be done on the both serum and plasma samples [65].

The interpretation of result of serologic tests depends of the subjects' risk of involvement. In the low risk population, such as blood donors or general population, occurrence of false positive results of EIA-2 is very high (40-50\%) compared with RIBA-2, while in high risk population, like referral laboratories, EIA-2 has false positive less than $1 \%$. Antibody screening assay, is the primary test for detecting anti$\mathrm{HCV}$, and for positive screening test, a more specific supplemental assay is needed $[65,67]$. However, these data show that supplemental anti-HCV testing is typically not essential in high risk patients with a positive anti-HCV screen test [64].

Revealing of HCV- RNA in serum by highly sensitive tests, such as reverse-transcription PCR, has become a progressively more important test for verifying the diagnosis of hepatitis $\mathrm{C}$, and also evaluating the response to antiviral therapy. Reverse- transcription PCR can also measure the quantity of HCV RNA in the blood, known as the viral load and determine the genotype of HCV. Positive PCR test indicates

\begin{tabular}{|l|l|l|l|}
\hline & \multicolumn{2}{|c|}{ Positive Predictive Value† (\%) } \\
\hline & $\begin{array}{l}\text { Sensitivity* } \\
(\%)\end{array}$ & Low Prevalence & High Prevalence \\
\hline EIA-1 & $70-80$ & $30-50$ & $70-85$ \\
\hline EIA-2 & $92-95$ & $50-61$ & $88-95$ \\
\hline EIA-3 & 97 & 25 & Not Done \\
\hline
\end{tabular}

Table 2: Sensitivity and positive predictive value of EIA for Anti-HCV

* Based on clinical findings and detection of HCV RNA by PCR.

† Compared with RIBA. that the infected patients progress to advance liver diseases [64]. HCV genotype is so helpful to determine the optimum duration of treatment. Absence of measurable HCV RNA by means of PCR is now the gold standard of successful treatment of patients with chronic hepatitis $\mathrm{C}$ [63].

\section{Recommendation}

Global eradication of Hepatitis C Virus (HCV) is feasible by using a group of activities, including prevention education, clinical and population screening, delivery of effective care and treatment to withdraw the source of infection, and development of update health policy regarding distribution of HCV in the community [68,69] (Figure 1). Case finding of HCV patients among all visiting in the clinics and private offices, and universal screening of high risk population is a useful strategy to eradicate $\mathrm{HCV}$ worldwide. But, it needs an abundant funding and most countries are not able to develop this strategy. In 2004, the U.S. Preventive Services Task Force (USPSTF) suggested HCV screening in adults not at increased risk (D recommendation) [70]. Growing number of detecting asymptomatic patients and delivery of effective therapeutic care, and also education of households and relatives may prevent the occurrence of new infection and discontinue the 'silent epidemic' [69].

Unfortunately, there not found effective vaccine against $\mathrm{HCV}$, because of its noticeable genetic diversity and several means of persistence of $\mathrm{HCV}$, however great advances have been raised in the treatment of hepatitis C patients [71].

Elimination of occurrence of new episode of hepatitis $C$, and also decreasing burden of $\mathrm{HCV}$ infection, requires implementation of comprehensive strategy involve all levels of prevention activities, including primary prevention to decrease the risk of transmission of $\mathrm{HCV}$ infection and secondary prevention to reduce the risk of chronic liver diseases in HCV patients by early diagnosis and introducing the suitable management of $\mathrm{HCV}$-infected persons.

\section{Primary Prevention}

Primary prevention of hepatitis $\mathrm{C}$, as an activity to prevent the disease from occurring, includes activities to reduce or eliminate transmission of HCV to vulnerable persons, and focuses on decreasing risk factors.

Blood, plasma, organ, tissue, and semen donors are a potential source of transmission of HCV. After introducing useful tests to detect $\mathrm{HCV}$, screening of donated blood and organs is suggested worldwide. On the other hand, those who have history of high risk behavior, such as IV drug abusing, are refused to donate. Another strategy in blood banks is the virus inactivation of plasma-derived products. Nowadays, donated blood, plasma, organ, tissue, and semen are very rarely infected by important blood-borne pathogens, including human immunodeficiency virus (HIV), hepatitis B virus (HBV) and HCV.

Transmission of HCV likely occurs via health care system, so that health care professionals can spread infection to patients and vice-versa. There is no an actual rule to restricts health care workers to prohibit from delivery of exposure-prone procedures. Society for Healthcare Epidemiology of America (SHEA) recommends that health care professionals with circulating HCV viral burdens of more than or equal to $10^{4} \mathrm{GE} / \mathrm{mL}$ (genome equivalents per milliliter) regularly use double-gloving for all invasive procedures, for all contact with mucous membranes or nonintact skin, and for all cases in patient care for which gloving is routinely suggested. In Category III activities, due to high 


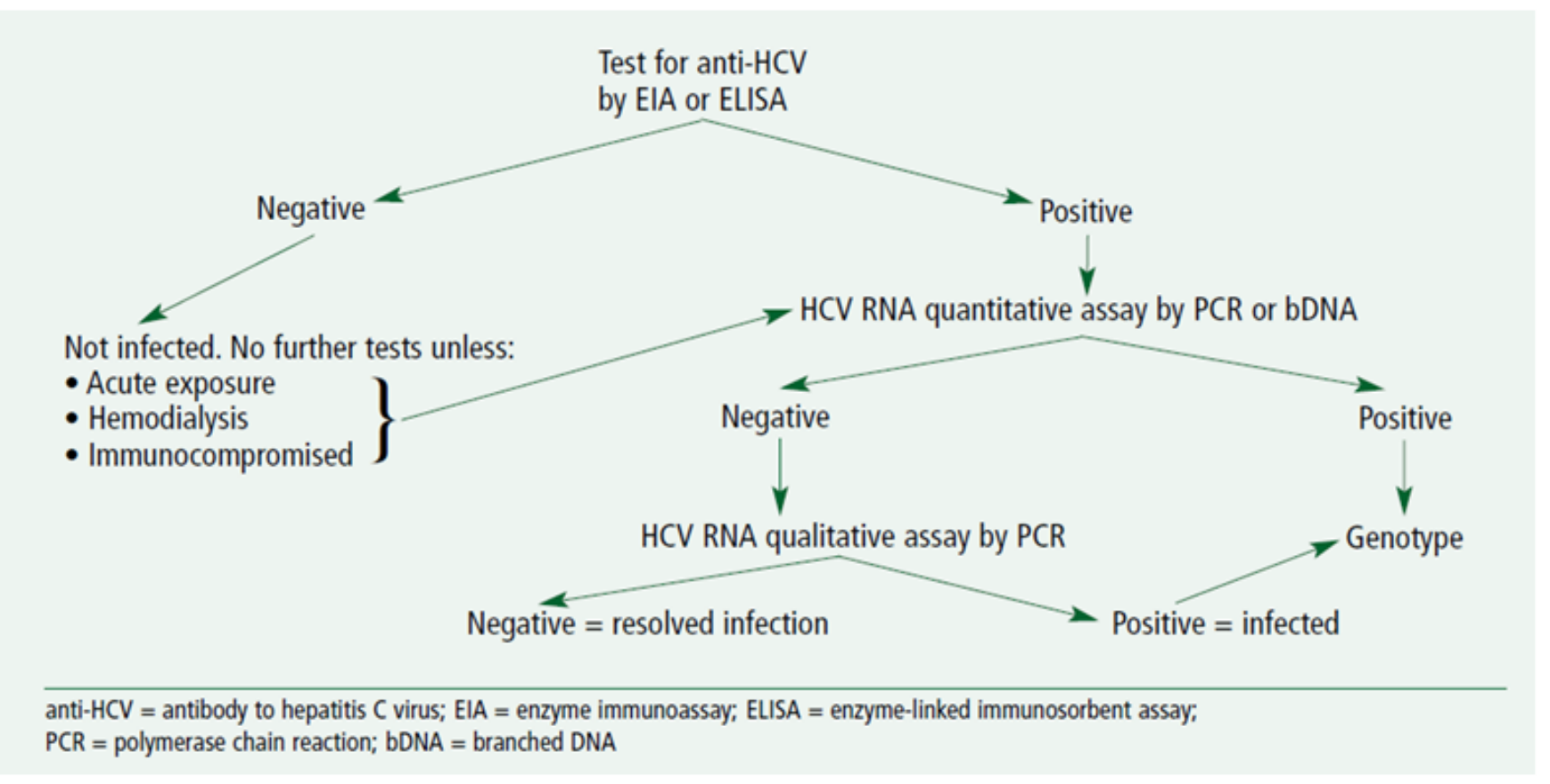

Figure 1: Represents algorithm for laboratory testing of suspected HCV infection [69].

risk for provider-to-patient transmission of bloodborne pathogen, applying proper infection control procedures is critically advised. As well, SHEA recommends that an HCV-infected provider with a viral burden of less than $104 \mathrm{GE} / \mathrm{mL}$ not be excluded from any aspect of patient care, including the performance of Category III procedures. They must evaluate for viral burden twice annually, and consult with a specialist [72]. Level of risk for bloodborne pathogen transmission are classified into three categories: Category I: Procedures with de minimis risk of bloodborne virus transmission; Category II: Procedures for which bloodborne virus transmission is theoretically possible but unlikely; Category III: Procedures for which there is definite risk of bloodborne virus transmission or that have been classified previously as "exposure-prone" $[72,73]$.

Precautions in hemodialysis center are more rigorous than traditional precautions. When patients or hemodialysis equipment is touched, use of gloves is recommended, even there are no blood, secretion and contaminated fluid. Supplies, instruments, and medications of each patient must not share with others. Clean and contaminated sections should be separated [74]. Table 3 presents persons who should be tested routinely for HCV.

Counseling and education of people to avoid risk factors, such as IV drug abusing and having multiple sex partners, is another primary prevention activity. Those who want to continue high risk behavior should be counseled to do activities minimizing the likelihood of transmission of infection. Vaccination against hepatitis B and hepatitis $\mathrm{A}$ is recommended among persons with high risk behavior. IV drug abusers should not share syringes, drugs, and equipment, use the new and sterile syringes, and dispose syringes and equipment after using illegal drugs. Equipment and injection site must be thoroughly cleaned by a new alcohol swab $[74,75]$. Syringe and needle-exchange programs can be an efficient policy to diminish the rate of bloodborne virus transmission $[75,76]$.

Persons with multiple sex partners are at risk for sexually transmitted diseases, such as HCV infection. They are consulted to have sex with merely one uninfected partner or not to have sex at all. Latex condoms should be used for every sexual contact to avoid spreading of HCV between partners [74]. Targeted programs can raise awareness about the advantage of condom use and possible sexual risk associated with regular partners [77].

Cosmetic procedures, in which something penetrate the skin barrier like tattooing or body piercing, should be performed by sterile supplies and instruments and following proper infection-control activities in a verified center.

Introducing risk-reduction programs and consultation of people, especially high risk population, might decrease the incidence of hepatitis $\mathrm{C}$. This activity includes:

- $\quad$ decreasing the number of sex partners and needle-sharing partners

- $\quad$ increasing use of condoms

- Not sharing household items which may contaminated with blood, e.g. razors, toothbrushes, nail clippers, and snorting straws

- $\quad$ adhering to medication

- taking an active role in medical care

- $\quad$ Not using alcohol

- $\quad$ abstinence

- Referral to required psychological, social, and medical services affecting risk behavior [78,79].

Implementation and maintenance of infection-control practices, including prompt removal and surface disinfection of an area contaminated by either blood or body substances and following aseptic procedures are other way of preventing HCV spreading [80]. 


\begin{tabular}{|l|}
\hline Persons who should be tested routinely for hepatitis C virus (HCV) infection based \\
\hline on their risk for infection \\
\hline - Persons who ever injected illegal drugs, including those who injected once ora few times many years ago and do not consider themselves as drug users. \\
\hline - Persons with selected medical conditions, including \\
\hline - persons who received clotting factor concentrates produced before $1987^{\star}$ \\
\hline - persons who were ever on chronic (long-term) hemodialysis; and \\
\hline - Persons with persistently abnormal alanine aminotransferase levels. \\
\hline - Prior recipients of transfusions or organ transplants, including \\
\hline - persons who were notified that they received blood from a donor who latertested positive for HCV infection; \\
\hline - persons who received a transfusion of blood or blood components beforeJuly 1992; and \\
\hline - Persons who received an organ transplant before July $1992^{*}$. \\
\hline Persons who should be tested routinely for HCV-infection based on a recognized exposure \\
\hline - Healthcare, emergency medical and public safety workers after needle sticks,sharps, or mucosal exposures to HCV-positive blood. \\
\hline - Children born to HCV-positive women. \\
* These times may differ in various countries. \\
\hline
\end{tabular}

Table 3: Persons who should be tested routinely for HCV [75]

\section{Secondary Prevention}

Secondary prevention includes diagnosis and treatment of diseases in early stages before it causes significant morbidity. HCV antiviral treatment, regardless of the HCV genotype, patient age, and comorbidities, results in Sustained Virologic Response (SVR) in many patients that lead to improved survival and reduced liver-related and all-cause mortality [81].

\section{Screening for Hepatitis C Virus}

In 1998, the Centers for Disease Control and Prevention recommended that HCV testing is routinely done to persons most likely to be infected with HCV [74]. Whole population screening is neither cost- effective nor practical [82]. In this setting, screening of persons at risk of affecting HCV is recommended. The best way to take it is to be asked first about the risk of exposure to HCV from those who look for care from health care centers and those with risk factors are screened for HCV antibodies [83].

Persons at risk of $\mathrm{HCV}$ infection can be grouped into high, intermediate, or low risk as following:

- Groups at high risk of HCV:

- Intravenous drug abusers (past or present)

- patients treated with clotting factor concentrates (like Hemophilia patients) produced before 1987 (This time may differ in various countries)

- $\quad$ People infected with HIV

- Groups at intermediate risk of HCV:

- Receipt of blood or blood components (red cells, platelets, fresh-frozen plasma) transfusions before 1992 (This time may differ in various countries)

- Receipt of solid-organ transplants before 1992 (This time may differ in various countries)

- $\quad$ Long-term hemodialysis

- $\quad$ Patients with unexplained elevated aminotransferase levels

- Infants born to infected mothers

- Groups at low risk of HCV:
- $\quad$ People who have had sexual relations with multiple or an infected steady partner

- Health care workers exposed to HCV, eg, by needlestick $[74,82]$.

- IV drug abuse is the most important independent risk factor for HCV infection. Persons should be questioned for history of IV drug abuse, either in the past or present, in health care centers. Those with this risk factor should be tested for HCV antibodies. Limited or occasional use, even once, should be tested $[74,82]$.

- Hemophilia patients received clotting factor concentrates produced before 1987 and patients with long- term hemodialysis should be evaluated for HCV antibodies. Periodic testing of hemodialysis patients is not suggested [84].

- $\quad$ Elevated AST level, in addition to increased ALT level, is an indication of looking for cause of liver disorder, including HCV antibody [74].

- Nowadays, donated bloods and organ transplants are screened for HCV antibody. But, before screening program (before July 1992), recipients might be infected with HCV virus. So, they should be evaluated for infection of hepatitis $\mathrm{C}$ virus. However, time of beginning of screening program of donated blood and organ transplants may differ between various countries $[29,74]$.

- The prevalence of HCV infection in health care workers in not higher than general population. Health care facilities must establish policies to evaluate HCV and other important blood- borne infection among personnel affecting by needle stick or mucosal exposure to HCV- positive blood. After exposure to blood, the patient must be tested for HCV infection. Anti- HCV and serum level of ALT are evaluated at baseline and after 4-6 months in health care providers. If you want for early diagnosis, PCR for HCV-RNA is suggested at 4-6 weeks. Immunoglobulin and antiviral agents are not suggested for post- exposure prophylaxis of hepatitis C [74].

- Transmission of HCV from infected mother to her child is a rare evident. HCV is transmitted to $2 \%$ of newborns of anti-HCV seropositive mothers and $4 \%$ to $7 \%$ of newborns of HCV-RNA positive mothers at delivery, especially HCV- RNA levels $>106$ copies/mL [85]. Immunoglobulin and antiviral agents are not suggested for postexposure prophylaxis of hepatitis $\mathrm{C}$ for infants born to $\mathrm{HCV}$ - positive mothers [74]. The type of delivery doesn't influence the frequency of HCV transmission, except those who have HIV infection co-morbidity 
[86]. Breastfeeding doesn't meaningfully affect HCV transmission. Frequency of transmission for breastfed and no breastfed infants are $3.7 \%$ and $3.9 \%$, respectively [85]. Fetal scalp electrodes and prolonged rupture of membranes should be prohibited. HCV- RNA in 2 and 6 months and HCV antibody after 15 months should be tested. Testing HCV antibody should not be before 12- month. Umbilical cord sampling may be associated with increased risk of transmission, so this procedure should be avoided for early diagnosis of perinatal HCV infection. In the positive children, HCV RNA levels higher than $50 \mathrm{IU} /$ $\mathrm{mL}$ and evidence of portal or bridging fibrosis and inflammation in liver biopsy is the indication of antiviral therapy with peg-interferon and ribavirin after 3 years of age [86].

- Screening of HCV infection is not routinely recommended in health care workers, pregnant women, household nonsexual contacts with HCV positive patients and general population. They are tested in the individual cases, including having risk factors or exposure with blood of infected persons [74].

- The need of routine testing of HCV antibody has not yet determined among those who have some risk factors of $\mathrm{HCV}$ transmission, including receipts of transplanted tissue (e.g., corneal, musculoskeletal, skin, ova, sperm), use of intranasal cocaine and other non- injecting illegal drug, history of tattooing or body piercing, history of having multiple sex partners or sexually transmitted diseases, and having long-term steady sex with HCV-positive persons [74].

\section{Conclusion}

Hepatitis C, as an important cause of morbidity, needs special attention from health policy makers, health care workers, and general population. Hepatitis $\mathrm{C}$ has no effective vaccine. So, it should be considered among those look for health care, especially those with risk factors. Considering counseling and education of people to avoid risk factors, such as IV drug abusing and having multiple sex partners, are important primary prevention activities.Public health surveillance is an effective strategy to detect new cases, risk factors and burden of disease. Early diagnosis and prompt treatment by expert specialists can decrease hepatitis $\mathrm{C}$ and HCV-related diseases prevalence, disease sequel and burden of hepatitis $\mathrm{C}$. Increased knowledge about natural history of $\mathrm{HCV}$, prevalence of hepatitis $\mathrm{C}$ in general population and selected population with known risk factors may guide the policy makers to establish a newer effective strategy to decrease the burden of disease. Monitoring and assessment of preventive programs is required to identify the strength and weakness of program and to re-establish newer one.

\section{References}

1. Lavanchy D (2011) Evolving epidemiology of hepatitis C virus. ClinMicrobiol Infect 17: 107-115.

2. Brown RS Jr, Gaglio PJ (2003) Scope of worldwide hepatitis C problem. Liver Transpl 9: S10-13.

3. Alavian S (2008) We need a new national approach to control hepatitis C: It is becoming too late. Hepatitis Monthly 8: 1-3.

4. Alizadeh AH, Ranjbar M, Yadollahzadeh M (2008) Patient concerns regarding chronic hepatitis B and C infection. East Mediterr Health J 14: 1142-1147.

5. Perz JF, Armstrong GL, Farrington LA, Hutin YJ, Bell BP (2006) The contributions of hepatitis $B$ virus and hepatitis $C$ virus infections to cirrhosis and primary liver cancer worldwide. J Hepatol 45: 529-538.

6. MohdHanafiah K, Groeger J, Flaxman AD, Wiersma ST (2013) Global epidemiology of hepatitis $C$ virus infection: new estimates of age-specific antibody to HCV seroprevalence. Hepatology 57: 1333-1342.

7. Razjou F, Maghsudlu M, Nasizadeh S, Zadsar M (2012) The impact of donor selection on blood safety in Iran. TransfusApherSci 47: 13-16.
8. Sharifi-Mood B, Khosravi S (2006) Tattooing: A major source for viral infection. Journal of Medical Sciences 6:678-680.

9. Mohammad Alizadeh AH, Alavian SM, Jafari K, Yazdi N (2005) Prevalence of hepatitis $\mathrm{C}$ virus infection and its related risk factors in drug abuser prisoners in Hamedan--Iran. World J Gastroenterol 11: 4085-4089.

10. Alavian SM, Fallahian F (2008) Comparison of seroepidemiology and transmission modes of viral hepatitis $\mathrm{C}$ in Iran and Pakistan. Hepatitis Monthly 8:51-59.

11. Liang TJ (2013) Current progress in development of hepatitis $C$ virus vaccines. Nat Med 19: 869-878.

12. Smith BD, Morgan RL, Beckett GA, Falck-Ytter Y, Holtzman D, et al. (2012) Recommendations for the identification of chronic hepatitis $C$ virus infection among persons born during 1945-1965. MMWR Recomm Rep 61: 1-32.

13. Global Burden Of Hepatitis C Working Group (2004) Global burden of disease (GBD) for hepatitis C. J ClinPharmacol 44: 20-29.

14. Ray Kim W (2002) Global epidemiology and burden of hepatitis C. Microbes Infect 4: 1219-1225.

15. Shepard CW, Finelli L, Alter MJ (2005) Global epidemiology of hepatitis C virus infection. Lancet Infect Dis 5: 558-567.

16. Chemaitelly H, Abu-Raddad LJ, Miller FD (2013) An apparent lack of epidemiologic association between hepatitis $C$ virus knowledge and the prevalence of hepatitis $\mathrm{C}$ infection in a national survey in Egypt. PLoS One 8 : e69803.

17. Lehman EM, Wilson ML (2009) Epidemiology of hepatitis viruses among hepatocellular carcinoma cases and healthy people in Egypt: a systematic review and meta-analysis. International journal of cancer Journal international du cancer 124:690-697.

18. Hepatitis C: global prevalence. WklyEpidemiol Rec. 1997;72:65-69.

19. Frank C, Mohamed MK, Strickland GT, Lavanchy D, Arthur RR, et al. (2000) The role of parenteral antischistosomal therapy in the spread of hepatitis $C$ virus in Egypt. Lancet 355: 887-891.

20. Lehman EM, Wilson ML (2009) Epidemic hepatitis C virus infection in Egypt: estimates of past incidence and future morbidity and mortality. J Viral Hepat 16: $650-658$

21. Palitzsch KD, Hottenträger $B$, Schlottmann $K$, Frick $E$, Holstege $A$, et al. (1999) Prevalence of antibodies against hepatitis $C$ virus in the adult German population. Eur J GastroenterolHepatol 11: 1215-1220.

22. Zou S, Tepper M, El Saadany S (2000) Prediction of hepatitis C burden in Canada. Can J Gastroenterol 14: 575-580.

23. Alter MJ, Kruszon-Moran D, Nainan OV, McQuillan GM, Gao F, et al. (1999) The prevalence of hepatitis $C$ virus infection in the United States, 1988 through 1994. N Engl J Med 341: 556-562.

24. Ohshima S, Komatsu M, Nakane K, Meng XW, Goto T, et al. (2000) latrogenic $G B$ virus $C$ /hepatitis $G$ virus infection in an area endemic for hepatitis $C$ virus. J Hosp Infect 44: 179-185.

25. Ito S, Ito M Cho MJ, Shimotohno K Tajima K (1991) Massive seroepidemiological survey of hepatitis $C$ virus: clustering of carriers on the southwest coast of Tsushima, Japan. Jpn J Cancer Res 82: 1-3.

26. Hayashi J, Nakashima K, Yoshimura E, Hirata M, Maeda Y, et al. (1994) Detection of HCV RNA in subjects with antibody to hepatitis $C$ virus among the general population of Fukuoka, Japan. J Gastroenterol 29: 147-151.

27. Puro V, Petrosillo N, Ippolito G, Aloisi MS, Boumis E, et al. (1995) Occupationa hepatitis $C$ virus infection in Italian health care workers. Italian Study Group on Occupational Risk of Bloodborne Infections. Am J Public Health 85: 1272-1275.

28. Alavian SM (2009) Hepatitis C infection in Iran; A review article. Iranian Journal of Clinical Infectious Diseases 4:47-59.

29. Mahmoodian-Shooshtari M, Pourfathollah A (2006) An overview analysis of blood donation in the Islamic Republic of Iran. Arch Iran Med 9: 200-203.

30. Diaz T, Des Jarlais DC, Vlahov D, Perlis TE, Edwards V, et al. (2001) Factors associated with prevalent hepatitis $C$ : differences among young adult injection drug users in lower and upper Manhattan, New York City. Am J Public Health 91: 23-30. 
Citation: Shalmani HM, Ranjbar M, Alizadeh AHM (2013) Recommendations for Prevention and Control of Hepatitis C Virus (HCV) Infection and HCV-Related Chronic Disease. J Liver 3: 147. doi:10.4172/2167-0889.1000147

Page 7 of 8

31. Zali MR NA, Amirrasooli H, Darvishi M (1998) Prevalence of Anti-HCV antibody and routes of hematological transmission in addicts of Ghasr prison [in persian] Pajouhesh22:26-32.

32. Garfein RS, Vlahov D, Galai N, Doherty MC, Nelson KE (1996) Viral infections in short-term injection drug users: the prevalence of the hepatitis $C$, hepatitis $\mathrm{B}$, human immunodeficiency, and human T-lymphotropic viruses. Am J Public Health 86: 655-661.

33. Tillmann HL, Manns MP (1996) Mode of hepatitis C virus infection, epidemiology, and chronicity rate in the general population and risk groups. Dig Dis Sci 41: 27S-40S.

34. Alavian SM, Ahmadzad-Asl M, BagheriLankarani K, Shahbabaie MA BahramiAhmadi A, et al. (2009) Hepatitis C infection in the general population of iran: a systematic review. Hepat Mon 9:211-223.

35. Akbari A, Imanieh MH, Karimi M, Tabatabaee HR (2007) Hepatitis C virus antibody positive cases in multitransfusedthalassemic patients in south of Iran. Hepatitis Monthly 7:63-66.

36. Mansour-Ghanaei F, Fallah MS, Shafaghi A, Yousefi-Mashhoor M, Ramezani $\mathrm{N}$, et al. (2002) Prevalence of hepatitis $\mathrm{B}$ and $\mathrm{C}$ seromarkers and abnormal liver function tests among hemophiliacs in Guilan (northern province of Iran). Med SciMonit. 8:CR797-800.

37. Alavian SM, Bagheri-Lankarani K, Mahdavi-Mazdeh M, Nourozi S (2008) Hepatitis $B$ and $C$ in dialysis units in Iran: changing the epidemiology. Hemodiallnt 12: 378-382.

38. Alavian SM, Gholami B, Masarrat S (2002) Hepatitis C risk factors in Iranian volunteer blood donors: a case-control study. J GastroenterolHepatol 17: 10921097.

39. Hajiani E, Hashemi J, Masjedizadeh R, Shayesteh AA, Idani E, et al. (2006) Seroepidemiology of hepatitis $C$ and its risk factors in Khuzestan Province, south-west of Iran: a case-control study. World J Gastroenterol 12: 4884-4887.

40. Tovo PA, Pembrey LJ, Newell ML (2000) Persistence rate and progression of vertically acquired hepatitis $C$ infection. European Paediatric Hepatitis $C$ Virus Infection. J Infect Dis 181: 419-424.

41. Alter MJ (2002) Prevention of spread of hepatitis C. Hepatology 36: S93-98.

42. Dore G, Law M, MacDonald M, Kaldor J (2003) Epidemiology of hepatitis C virus infection in Australia. J ClinVirol 26:171-184.

43. Tallis GF, Ryan GM, Lambert SB, Bowden DS, McCaw R, et al. (2003) Evidence of patient-to-patient transmission of hepatitis $\mathrm{C}$ virus through contaminated intravenous anaesthetic ampoules. J Viral Hepat 10: 234-239.

44. Norder H, Bergström A, Uhnoo I, Aldén J, Weiss L, et al. (1998) Confirmation of nosocomial transmission of hepatitis $C$ virus by phylogenetic analysis of the NS5-B region. J ClinMicrobiol 36: 3066-3069.

45. Chung H, Kudo M, Kumada T, Katsushima S, Okano A, et al. (2003) Risk of $\mathrm{HCV}$ transmission after needlestick injury, and the efficacy of short-duration interferon administration to prevent HCV transmission to medical personnel. J Gastroenterol 38: 877-879.

46. Ferrero S, Lungaro P, Bruzzone BM, Gotta C, Bentivoglio G, et al. (2003) Prospective study of mother-to-infant transmission of hepatitis $C$ virus: a 10year survey (1990-2000). ActaObstetGynecolScand 82: 229-234.

47. Pawlotsky JM, Tsakiris L, Roudot-Thoraval F, Pellet C, Stuyver L, et al. (1995) Relationship between hepatitis $C$ virus genotypes and sources of infection in patients with chronic hepatitis C. J Infect Dis 171: 1607-1610.

48. McOmish F, Chan S, Dow B, Gillon J, Frame W, et al. (1993) Detection of three types of hepatitis $C$ virus in blood donors: investigation of type-specific differences in serologic reactivity and rate of alanine aminotransferase abnormalities. Transfusion33:7-13.

49. Driesel G, Wirth D, Stark K, Baumgarten R, Sucker U, et al. (1994) Hepatitis C virus (HCV) genotype distribution in German isolates: studies on the sequence variability in the E2 and NS5 region. Arch Virol 139: 379-388.

50. Simmonds P, Bukh J, Combet C, Deléage G, Enomoto N, et al. (2005) Consensus proposals for a unified system of nomenclature of hepatitis $\mathrm{C}$ virus genotypes. Hepatology 42: 962-973

51. Zeuzem S, Franke A, Lee JH, Herrmann G, Ruster B, et al. (1996) Phylogenetic analysis of hepatitis $C$ virus isolates and their correlation to viremia, live function tests, and histology. Hepatology 24: 1003-1009.
52. Bartenschlager R, Penin F, Lohmann V, André $P$ (2011) Assembly of infectious hepatitis $C$ virus particles. Trends Microbiol 19: 95-103.

53. Minakari M, Sameni FK, Shalmani HM, Molaee M, Zali MR (2008) Hepatic steatosis in Iranian patients with chronic hepatitis C. Med PrincPract 17: 126130

54. Aach RD, Stevens CE, Hollinger FB, Mosley JW, Peterson DA, et al. (1991) Hepatitis $C$ virus infection in post-transfusion hepatitis. An analysis with firstand second-generation assays. N Engl J Med 325: 1325-1329.

55. Seeff LB (2009) The history of the "natural history" of hepatitis C (1968-2009). Liver Int 29 Suppl 1: 89-99.

56. Missiha SB, Ostrowski M, Heathcote EJ (2008) Disease progression in chronic hepatitis C: modifiable and nonmodifiable factors. Gastroenterology 134: 16991714.

57. Thimme R, Bukh J, Spangenberg HC, Wieland S, Pemberton J, et al. (2002) Viral and immunological determinants of hepatitis $C$ virus clearance persistence, and disease. ProcNatlAcadSci U S A 99: 15661-15668.

58. Thomas DL, Seeff LB (2005) Natural history of hepatitis C. Clin Liver Dis 9 : 383-398, vi.

59. El-Serag HB (2012) Epidemiology of viral hepatitis and hepatocellular carcinoma. Gastroenterology 142:1264-1273.e1.

60. Ramia S, Eid-Fares J (2006) Distribution of hepatitis C virus genotypes in the Middle East. Int J Infect Dis 10: 272-277.

61. Keyvani H, Alizadeh AH, Alavian SM, Ranjbar M, Hatami S (2007) Distribution frequency of hepatitis $C$ virus genotypes in 2231 patients in Iran. Hepatol Res 37: 101-103.

62. Zali MR, Mayumi M, Raoufi M, Nowroozi A (2000) Hepatitis C virus genotypes in the Islamic Republic of Iran: a preliminary study. East Mediterr Health J 6 : 372-377.

63. Carithers RL Jr, Marquardt A, Gretch DR (2000) Diagnostic testing for hepatitis C. Semin Liver Dis 20: 159-171.

64. Gretch DR (1997) Diagnostic tests for hepatitis C. Hepatology 26: 43S-47S.

65. Alter MJ, Kuhnert WL, Finelli L; Centers for Disease Control and Prevention (2003) Guidelines for laboratory testing and result reporting of antibody to hepatitis $\mathrm{C}$ virus. Centers for Disease Control and Prevention. MMWR Recomm Rep 52: 1-13, 15.

66. Younossi Z, McHutchison J (1996) Serological tests for HCV infection. Viral Hepatitis Rev 2:161-173.

67. Centers for Disease Control and Prevention (CDC) (2013) Testing for HCV infection: an update of guidance for clinicians and laboratorians. MMWR Morb Mortal Wkly Rep 62: 362-365

68. Carey W (2003) Tests and screening strategies for the diagnosis of hepatitis C Cleve Clin J Med 70 Suppl 4: S7-13.

69. Hagan LM, Schinazi RF (2013) Best strategies for global HCV eradication Liver Int 33: 68-79.

70. US. Preventive Services Task Force (2004) Screening for hepatitis C virus infection in adults: recommendation statement. Ann Intern Med 140: 462-464.

71. Henderson DK, Dembry L, Fishman NO, Grady C, Lundstrom T, et al. (2010) SHEA guideline for management of healthcare workers who are infected with hepatitis $B$ virus, hepatitis $C$ virus, and/or human immunodeficiency virus. Infect Control Hosp Epidemiol 31: 203-232.

72. Reitsma AM, Closen ML, Cunningham M, Lombardo PA, Minich HN, et al. (2005) Infected physicians and invasive procedures: safe practice management. Clin Infect Dis 40: 1665-1672.

73. Recommendations for prevention and control of hepatitis $\mathrm{C}$ virus (HCV) infection and HCV-related chronic disease (1998) Centers for Disease Control and Prevention. MMWR Recomm Rep 47(Rr-19): 1-39.

74. Hagan H, Jarlais DC, Friedman SR, Purchase D, Alter MJ (1995) Reduced risk of hepatitis $B$ and hepatitis $C$ among injection drug users in the Tacoma syringe exchange program. Am J Public Health 85: 1531-1537.

75. Dolan K, MacDonald M, Silins E, Topp L (2005) Needle and syringe programs: A review of the evidence. Canberra: Australian Government Department of Health and Ageing. 
Citation: Shalmani HM, Ranjbar M, Alizadeh AHM (2013) Recommendations for Prevention and Control of Hepatitis C Virus (HCV) Infection and HCV-Related Chronic Disease. J Liver 3: 147. doi:10.4172/2167-0889.1000147

Page 8 of 8

76. Islam MM, Topp L, Conigrave KM, Haber PS, White A, et al. (2013) Sexually transmitted infections, sexual risk behaviours and perceived barriers to safe sex among drug users. Aust N Z J Public Health 37: 311-315.

77. CDC. Comprehensive risk counseling and services for persons living with HIV.

78. Narelle Ellendon R (2004) Hepatitis C counseling; best practice manual. New York, NY: The Hepatitis C Harm Reduction Project.

79. CDC (2003) Guidelines for environmental infection control in health-care facilities. Atlanta, GA: U.S. Department of Health and Human Services; Centers for Disease Control and Prevention (CDC)

80. Backus LI, Boothroyd DB, Phillips BR, Belperio P, Halloran J, et al. (2011) A sustained virologic response reduces risk of all-cause mortality in patients with hepatitis C. Clin Gastroenterol Hepatol 9: 509-516.

81. Albeldawi M, Ruiz-Rodriguez E, Carey WD (2010) Hepatitis C virus: Prevention, screening, and interpretation of assays. Cleve Clin J Med 77: 616-626.
82. Alter MJ, Seeff LB, Bacon BR, Thomas DL, Rigsby MO, et al. (2004) Testing for hepatitis $C$ virus infection should be routine for persons at increased risk for infection. Ann Intern Med 141: 715-717.

83. [No authors listed] (2001) Recommendations for preventing transmission of infections among chronic hemodialysis patients. MMWR Recomm Rep 50: $1-43$.

84. Yeung LT, King SM, Roberts EA (2001) Mother-to-infant transmission of hepatitis $C$ virus. Hepatology 34: 223-229.

85. Powell M, Bailey J, Maggio LA (2010) Clinical inquiries. How should you manage children born to hepatitis C-positive women? J Fam Pract 59: 289-290.

86. Statement. NloHCC. Management of hepatitis C: 2002 [cited August 21, 2013] 